\title{
Breeding Status of Wild Doves in Bangladesh
}

\author{
Ashraful Kabir* \\ Department of Biology, Saidpur Cantonment Public College, Nilphamari, Bangladesh
}

*Corresponding Author: Ashraful Kabir, Department of Biology, Saidpur Cantonment Public College, Nilphamari, Bangladesh

Out of 17 species of wild doves in Bangladesh their incubation period ranges from 12-20 and fledging 12-27 days. Within these 14 species were in Least Concern (LC), 2 Data Deficit (DD), and 1 Critically Endangered (CR). Among these maximum numbers were found in the genus Treron (6) then Streptopelia (4), Columba and Ducula each 2, and Spilopelia and Macropygia 1. Observed doves were bred mostly all the year round. For hunting or pet purpose people sometime catch them and rear in cage and ultimately birds'die. For strong 'Wildlife Act' now doves of Bangladesh are living well and are increasing everywhere in nature as well.

On the basis of evolutionary sequences pigeons/doves have great significance. It has lots of connecting links which are very important for the study of evolution. In fancy pigeons, their tumbling behaviour is an exceptional and peculiar characteristic which came through mutation then modified by millions of thousands selective breeding. From the history, we have found that pigeon/dove keeping was an ancient hobby of people. Large-sized birds are called pigeon and small are dove; but this is not true always. For message sending, pigeons had great commitment in the world. Now wild pigeons and doves in the world are 316 (Gibbs et al., 2001). Most of the birds are wild but some are now domesticated especially Rock Dove, Collared Dove, and Diamond Dove. Pigeons and doves are nice in colour and some are most beautiful and available in Bangladesh (Kabir, 2015). American Ground Dove is the smallest one (length 6 inches) and Australian Crowned Dove is the largest (36-37 inches) (Rahman 2004, p-54). Voice of these birds, parental care, and learning behaviour all are remarkable in this columbids. In aviary system, its rearing is easily maintained by anybody (Alderton, 2005). Semiintensive system is good for its breeding. For its breeding and management it needs ideal food ratio (Kabir, 2013). Indian emperor Akbar reared lots of nice pigeons in his Delhi court and workers performed some selective breeding (Kabir, 2014b). Most Australian pigeon are actually very hardy and generally long-lived. A range of different species originates from Asia for the abundance of mixed seed (Alderton 2005, p 239, 242, 244). The sexual dimorphism is very clear in doves (Grimmett et al., 2007, p 88, 92, 94). Wood Pigeon is very similar and the cousin of Rock Dove (Baker 1913, p-134). Collared Doves were resident since 1955. Barbari Dove is closely allied species and frequent aviary escapes (Fitter and Richardson 1973, p 81, 94). Chalcophaps indica is called Fool Dove because it is very easy to capture. These doves were kept at the zoo in 1856, and many times since (Alderson 1911, p 68-69). In order to conserve 17 types of wild doves in Bangladesh depending on their habitat and distribution this article is important at all.

Gibbs et al. (2001) wrote a book 'Pigeons and Doves: A Guide to the Pigeons and Doves of the World' which was the baseline of this manuscript. Then IUCN Bangladesh 2015 has published the present status of these 17 types of doves in Bangladesh with their global and local status (Table 1; Figure 1).

Treron genus is a group of fruit dove which shows much yellow green whereas Chalcophaps are metallic green. Ducula (Imperial Pigeon) possesses 14 tail feathers or rectrices. Barred plumage is found in Macropygia genus which is of course an exceptional feather pattern in dove family. Columba is very common and well known in pigeon family (54 species) (Gibbs et al., 2001, p-175); its tail feathers are blackish at tips. Individuals in Streptopelia they have collared neck and their tips of the 
tail feathers are white or gray (Ali and Ripley 1981, p 93-94). Spilopelia is same as Streptopelia which carries collared neck.

Table1. Showing the availability of doves in nature of Bangladesh

\begin{tabular}{|l|l|l|l|l|l|}
\hline Scientific Name (English Name) & Breeding Season & Egg & Hatching & Fledging & $\begin{array}{l}\text { *Bangladesh } \\
\text { Status }\end{array}$ \\
\hline $\begin{array}{l}\text { Columba livia intermedia, Strickland 1844 } \\
\text { (Blue Rock Pigeon) }\end{array}$ & All the year & $1-2$ & 18 & 21 & LC \\
\hline $\begin{array}{l}\text { C. punicea, Blyth 1842 (Pale-capped } \\
\text { Pigeon) }\end{array}$ & May-August & 1 & $17-20$ & 20 & CR \\
\hline $\begin{array}{l}\text { Treron phoenicoptera phoeniciptera } \\
\text { (Latham 1790) (Yellow-footed Green } \\
\text { Pigeon) }\end{array}$ & March-August & 2 & 21 & 22 & LC \\
\hline $\begin{array}{l}\text { T. apicauda apicauda, Blyth 1846 (Pin- } \\
\text { tailed Green Pigeon) }\end{array}$ & April-June & 2 & $17-20$ & 20 & LC \\
\hline $\begin{array}{l}\text { T. bicincta bicincta (Jerdon 1840) } \\
\text { (Orange-breasted Green Pigeon) }\end{array}$ & March-August & 2 & $12-14$ & $21-27$ & LC \\
\hline $\begin{array}{l}\text { T. curvirostra nipalensis (Hodgson 1836) } \\
\text { (Thick-billed Green Pigeon) }\end{array}$ & April-July & 2 & $12-14$ & $15-16$ & LC \\
\hline $\begin{array}{l}\text { T. pompadora phayrei (Blyth 1862) } \\
\text { (Ashy-headed Green Pigeon) }\end{array}$ & December-July & 2 & 20 & $15-16$ & LC \\
\hline $\begin{array}{l}\text { T. sphenura sphenura (Vigors 1832) } \\
\text { (Wedge-tailed Green Pigeon) }\end{array}$ & April-August & 2 & $12-14$ & $15-16$ & LC \\
\hline $\begin{array}{l}\text { Ducula aenea sylvatica (Tickell 1833) } \\
\text { (Green Imperial Pigeon) }\end{array}$ & All the year & $1-2$ & $15-19$ & 20 & LC \\
\hline $\begin{array}{l}\text { D. badia griseicapilla, Walden 1875 } \\
\text { (Mountain Imperial Pigeon) }\end{array}$ & $\begin{array}{l}\text { March-August (North) } \\
\text { January-May (South) }\end{array}$ & $1-2$ & 20 & $15-16$ & LC \\
\hline $\begin{array}{l}\text { Spilopelia chinensis tigrina (Temminck } \\
\text { 1810) (Eastern Spotted Dove) }\end{array}$ & All the year & $1-2$ & $12-16$ & $12-13$ & LC \\
\hline $\begin{array}{l}\text { Streptopelia senegalensis cambayensis (J. } \\
\text { F. Gmelin 1789) (Laughing Dove) }\end{array}$ & All the year & 2 & $12-14$ & $12-13$ & DD \\
\hline $\begin{array}{l}\text { S. tranquibarica tranquibarica (Hermann } \\
\text { 1804) (Red-collared Dove) }\end{array}$ & All the year & 2 & 13 & 14 & LC \\
\hline $\begin{array}{l}\text { S. decaocto decaocto (Frivaldszky 1838) } \\
\text { (Eurasian Collared Dove) }\end{array}$ & All the year & 2 & $14-18$ & $15-19$ & LC \\
\hline $\begin{array}{l}\text { S. orientalis agricola (Tickell 1833) } \\
\text { (Oriental Turtle Dove) }\end{array}$ & May-July & 2 & 20 & 15 & LC \\
\hline $\begin{array}{l}\text { Chalcophaps indica indica (Linnaeus } \\
\text { 1758) (Gray-capped Emerald Dove) }\end{array}$ & All the year & 2 & 17 & 21 & LC \\
\hline $\begin{array}{l}\text { Macropygia unchall tusalia (Blyth 1843) } \\
\text { (Barred Cuckoo Dove) }\end{array}$ & May-July & $1-2$ & $17-20$ & 20 & DD \\
\hline
\end{tabular}

*IUCN Bangladesh, Red Data Book, 2015

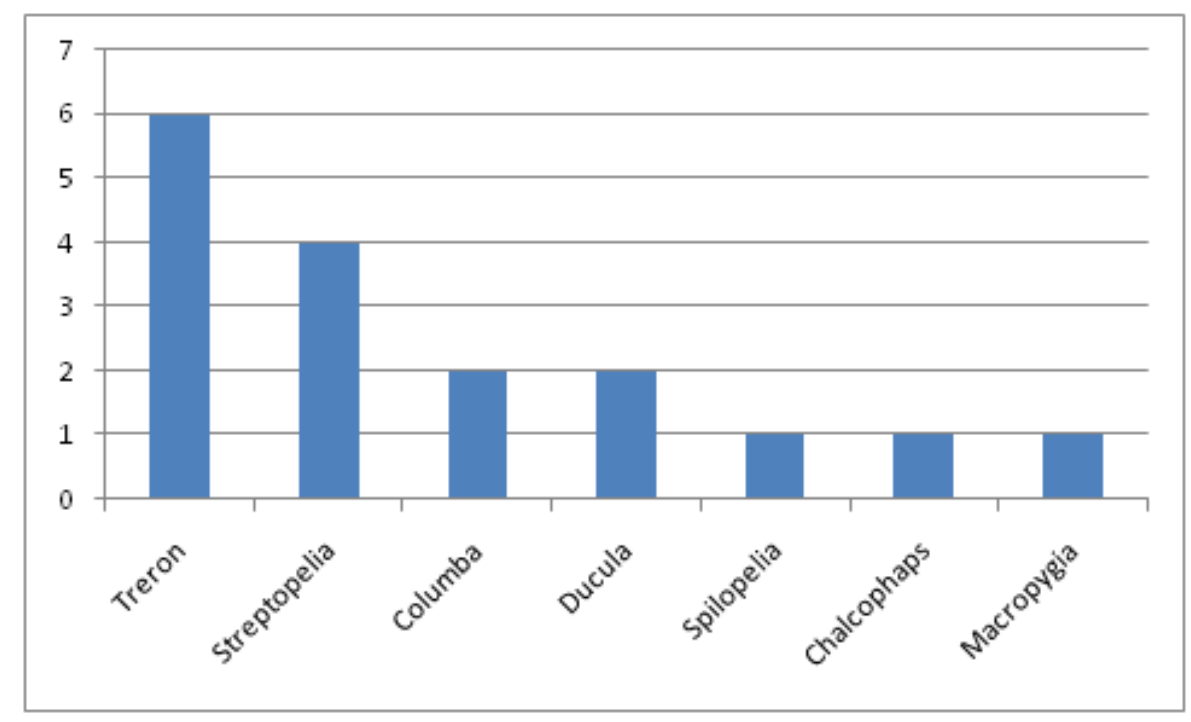

Figure1. Total species under the genus of doves 
From the history, we have known that some doves have been extinct from the world. Saint Helena Dove was the first extinct pigeon of the world but its time is still unknown then Liverpool Pigeon. Before 1690 Rodrigues Turtle Dove was extinct. In the year 1700 Reunion Pink Pigeon vanished. Late $17^{\text {th }}$ century very famous and pronounced Dodo has extinct. This Dodo was the leading of pigeons or doves of the world. 1730 Rodrigues Solitaire, 1800 Norfolk Island Ground Dove, mid $18^{\text {th }}$ century Rodrigues Grey Pigeon, 1830 Mauritius Blue Pigeon, 1890 Bonin Wood Pigeon, late $18-19^{\text {th }}$ century Tanna Ground Dove, very remarkable Passenger Pigeon in 1914, late 1930 Ryukyu Wood Pigeon, late 1990 Sulu Bleeding Heart, early $20^{\text {th }}$ century Choiseul Crested Pigeon, mid $20^{\text {th }}$ century Thick-billed Ground Dove and Red-moustached Fruit Dove and finally in late $20^{\text {th }}$ century Negros Fruit Dove has been extinct from the world. Baker in 1913 wrote a book on 'Indian Pigeons and Doves' with 51 species. He mentioned the references of Salvadori's Catalogue of Birds (volume 21) (columbidae), Avifauna of British India by Blanford's (volume 4) and pigeons susceptibility to different climatic variations by Beebe. Blanford's mentioned 45 dove species in his book. In India, it has different climatic variations so that subspecies are huge in doves. Baker described 51 species of doves with their sexual dimorphism, breeding, and various measurements. Rosie Alderson of London reared 40 doves and wrote a book on them where he mentioned their habitat, lengths, colouring, wild life, and life in captivity. His all pet doves were differed on their behaviour with the present 17 doves of Bangladesh (IUCN Bangladesh, 2015) except only Chalcophaps indica.

Dodo and Solitaire were the flightless pigeon and also the Sandgrouse, a group of birds resembling with the pigeons in some anatomical features. Sandgrouse are similar with the Plover. In British, pigeons are categorized into five-Wood Pigeon, Stock Pigeon, Rock Pigeon, Turtle Dove, and Collared Dove. Monotypic subspecies of Rock Pigeon Columba livia livia is very common in Europe and Columba livia intermedia is available in Indian Peninsular and in Bangladesh. Some subspecies of Rock Pigeon are very similar with others. By clear understanding within the Rock Pigeons, it is possible to find out super-species and semi-species. In wild state, varieties are usually less viable than normal birds and soon die or are killed. From the variety in the wild, scientists were discovered lots of breeds of pigeons and all are now recognized as fancy pigeons. Those breeds are well established domesticated variety that has been fixed by artificial selection to the extent that it 'breeds true' and produces offspring of the same appearance as itself. Colmba livia is sometimes called Columba domestica (Goodwin, 1970).

\section{REFERENCES}

[1] Alderson S. 1911. My Foreign Doves and Pigeons. 9 Arundel Street, London. 95 pp.

[2] Alderton D. 2005. The Ultimate Encyclopedia of Caged and Aviary Birds. Anness Publishing Ltd, London. $256 \mathrm{pp}$.

[3] Ali S and Ripley SD. 1981. Handbook of the Birds of India and Pakistan (2 ${ }^{\text {nd }}$ edn.). Vol 3. Oxford University Press, India. 327 pp.

[4] Baker ECS. 1913. Indian Pigeons and Doves. Witherby and Co., London. 260 pp.

[5] Fitter RSR and Richardson RA. 1973. Collins Pocket Guide to British Birds. Collins Sons and Co. Ltd, London. 287 pp.

[6] Gibbs D, Barnes E, Cox J. 2001. Pigeons and Doves: A Guide to the Pigeons and Doves of the World. Pica Press, London. 615 pp.

[7] Goodwin D. 1970. Pigeons and Doves of the World (2 $2^{\text {nd }}$ edn.). Trustees of the British Museum (Natural History). 446 pp.

[8] Grimmett R, Inskipp C, Inskipp T. 2007. Oxford Pocket Guide to the Birds of Indian Subcontinent. Oxford University Press, New Delhi, India. 384 pp.

[9] IUCN. 2015. Red Data Book. IUCN Bangladesh.Vol 4

[10] Kabir MA. 2014a. Breeding biology of domesticated Eurasian Collared Dove (Columbidae) Streptopelia decaocto Frivaldszky 1838 in Saidpur, Bangladesh. Intl. J. of Environment 3(2): 49-55.

[11] Kabir MA. 2014b. Known and unknown pigeons in mughal history. Social and Basic Sciences Research Review 2(5): 277-283.

[12] Kabir MA. 2015. Most beautiful pigeons of Bangladesh. Animal and Veterinary Sciences 3(2): 34-37.

[13] Kabir MA. 2013. Productivity of crossed indigenous pigeon in semi intensive system. Basic Res. J. Agric. Sci. Rev. 2(1): 1-4. 
[14] Levi WM. 1992. The Pigeon. Levi Publishing Company, Sumter SC. 640 pp.

[15] Rahman ANMA. 2004. Posha Pakhi Pakhi Posha (in Bangla). Nandini Printing and Publications, Shantinagar, Dhaka. 80 pp.

[16] Rahman MA. 1999. Kobutar Gajat (in Bangla). Zaman Printers, Mymensingh, Bangladesh. 83 pp.

[17] Salvadori T. 1893. Catalogue of the Birds (vol 21). Taylor and Francis, London. 734 pp.

Citation: Ashraful Kabi, "Breeding Status of Wild Doves in Bangladesh" International Journal of Research Studies in Zoology, vol. 6, no. 1, p. 1-4, 2020. DOI: http://dx.doi.org/10.20431/2454-941X.0601001.

Copyright: () 2020 Authors. This is an open-access article distributed under the terms of the Creative Commons Attribution License, which permits unrestricted use, distribution, and reproduction in any medium, provided the original author and source are credited. 